\title{
Religious Studies at 50
}

\section{Weetwood Hall, University of Leeds}

$$
25^{\text {th }}-27^{\text {th }} \text { June, } 2014
$$

\section{CALL FOR PAPERS}

To celebrate the publication of the $50^{\text {th }}$ volume of Religious Studies in 2014, and the forthcoming $50^{\text {th }}$ anniversary of the founding of the journal in 1965 , the University of Leeds is hosting a conference, sponsored by Cambridge University Press, on $25^{\text {th }}-27^{\text {th }}$ June, 2014. Invited participants include: Pamela Sue Anderson, Peter Byrne, Victoria Harrison, Brian Leftow, Graham Oppy, John Schellenberg, Stewart Sutherland, Richard Swinburne, and Keith Ward.

The afternoon of $26^{\text {th }}$ will be set aside for submitted short papers, and these are now invited. Abstracts of around 250 words, accompanied by a short CV, should be sent by e-mail attachment to the Editor, Prof. Robin Le Poidevin, r.d.lepoidevin@leeds.ac.uk, no later than $31^{\text {st }}$ January, 2014. 